\title{
On some inequalities for $s$-logarithmically convex functions in the second sense via fractional integrals
}

\section{MEVLÜT TunÇ and HAVva KAVURMACI-ÖNALAN}

\section{ABSTRACT.}

In this paper, the authors establish some new Hadamard type inequalities for $s$-logarithmically convex functions in the second sense via fractional integrals by using Lemma 1.1 which has been proved by Sarıaya et al.

\section{REFERENCES}

[1] Akdemir, A. O. and Tunç, M., On some integral inequalities for s-logarithmically convex functions, submitted, http://arxiv.org/pdf/1212.1584. pdf.

[2] Belarbi, S. and Dahmani, Z., On some new fractional integral inequalities, J. Ineq. Pure and Appl. Math., 10 (2009), No. 3, Art. 86

[3] Dahmani, Z., New inequalities in fractional integrals, International Journal of Nonlinear Science, 9 (2010), No. 4, 493-497

[4] Dahmani, Z., On Minkowski and Hermite-Hadamard integral inequalities via fractional integration, Ann. Funct. Anal., 1 (2010), No. 1, 51-58

[5] Dahmani, Z., Tabharit, L. and Taf, S., Some fractional integral inequalities, Nonl. Sci. Lett. A., 1 (2010), No. 2, 155-160

[6] Dahmani, Z., Tabharit, L. and Taf, S., New generalizations of Grüss inequality using Riemann-Liouville fractional integrals, Bull. Math. Anal. Appl., 2 (2010), No. 3, 93-99

[7] Hadamard, J., Étude sur les propriétés des fonctions entières et en particulier d'une fonction considerée par Riemann, J. Math Pures Appl., 58 (1893), $171-215$

[8] Iscan, I. and Wu, S., Hermite-Hadamard type inequalities for harmonically convex functions via fractional intergrals, Applied Mathematics and Computation, Accepted

[9] Kong, Q.-X. and Ding, X.-L., A New Fractional Integral Inequality with Singularity and Its Application, Abstract and Applied Analysis, Volume 2012, Article ID 937908, 12 pages, doi:10.1155/2012/937908

[10] Özdemir, M. E., Dragomir, S. S. and Yıldız, Ç., The Hadamard inequality for convex function via fractional integrals, RGMIA Research Report Collection, 15 (2012), art.14

[11] Özdemir, M. E., Kavurmac1, H. and Avc1, M. New inequalities of Ostrowski type for mappings whose derivatives are $(\alpha, m)$-convex via fractional integrals, RGMIA Research Report Collection, 15 (2012), Article 10

[12] Özdemir, M. E., Kavurmac1, H. and Yıldız, Ç., Fractional integral inequalities via s-convex functions, arXiv:1201.4915v1 [math.CA] 24 Jan 2012

[13] Özdemir, M. E. and Yıldız, Ç., The Hadamard's inequality for quasi-convex functions via fractional integrals, Annals of the University of Craiova, Math. and Comp. Sci. Series, 40 (2013), No. 2, 167-173

[14] Özdemir, M. E., Dragomir, S. S., and Yıldız, Ç., The Hadamard Inequality For Convex Function via Fractional Integrals, Acta Mathematica Scientia, 33B (2013), No. 5, 1293-1299

[15] Sarıkaya, M. Z., Set, E., Yaldız, H. and Başak, N., Hermite-Hadamard's inequalities for fractional integrals and related fractional inequalities, Math. and Comp. Modelling, 57 (2013), No. (9-10), 2403-2407

[16] Tunç, M., On new inequalities for h-convex functions via Riemann-Liouville fractional integration, Filomat, 27:4 (2013), 559-565, DOI 10.2298/FIL1304559T

[17] Tunç, M., Ostrowski type inequalities for $m$ - and $(\alpha, m)$-geometrically convex functions via Riemann-Louville Fractional integrals, http:/ /arxiv.org/pdf/1211.6587.pdf., submitted

[18] Xi, B.-Y., Qi, F., Some integral inequalities of Hermite-Hadamard type for s-logarithmically convex functions, Acta Mathematica Scientia Series B, English Edition, 34 (2014), in press

Department of Mathematics

Mustafa Kemal University

FACULTY OF SCIENCE AND ARTS

HATAY, 31000, TURKEY

E-mail address: mevluttttuncegmail.com

DEPARTMENT OF MATHEMATICS EdUCATION

VAN YÜZÜNCÜ YIL UNIVERSITY

FACULTY OF EDUCATION

VAN, TURKEY

E-mail address: havvaonalan@yyu.edu.tr 